\title{
The Legal Consequences of Supporting Candidates on Recommendation Sheets in an Illegal Way
}

\begin{abstract}
BY KLÁRA NAGY*
Abstract. In 2014 there were three elections in Hungary: the election of Members of Parliaments, the election of members of the European Parliament, furthermore, the elections of representatives and mayors of municipalities and of representatives of national minority local self-governments. The Hungarian Parliament passed a new act on electoral procedure in 2013 and we have had a new Criminal Code since 2012. This study examines a new legal institution, the recommendation sheets, which raise many questions, including criminal liability. The main theme of the study is the misuses related to recommendation sheets.
\end{abstract}

Keywords: supports on recommendation sheets, exchange of personal data, falsified signature on recommendation sheets, legal consequences according to criminal law

\section{INTRODUCTION}

The Hungarian Parliament has passed a new law on electoral procedure ${ }^{1}$ and a new Criminal Code $^{2}$. These acts had to be applied in the elections of 2014, too. I examine especially the regulations on recommendations. They have been changed and the new rules raise many questions.

Several misuses have happened. I try to answer the question how the acts should be modified in order to avoid these cases. How has criminal liability changed since the new rules on election have been in force? What kind of behaviour can lead to sanctions in criminal law?

I study cases which have happened, but it should be noted that in these cases court decisions have not necessarily been made. The current criminal regulation is the same as in the former Criminal Code. Thus, it is not an error if I refer to cases in which courts decided according to the former Criminal Code. ${ }^{3}$

\section{THE RULES ON RECOMMENDATIONS}

The Act on electoral procedure lays down the rules on the support of candidates. It says that the "support for candidates may be expressed on recommendation sheets". Recommendation sheets are not forwarded to voters, but they "may be requested (following the call for election) by voters who wish to become candidates and by nominating organizations from

1 The new Act is Act XXXVI of 2013, the former one is Act C of 1997.

2 The new Act is Act C of 2012, the former one is Act V of 1978.

${ }^{3}$ It is true even if the regulation on nominating candidates has been totally changed. In the past the voters got the proposal coupons via post. According to the new Act on electoral procedure voters do not get proposal coupons, but the candidate or the nominating organizations can require recommendation sheets, on which they can gather 8 nominations.

*Assistant lecturer, Széchenyi István University, Department of Criminal Sciences; Head of the Municipal Unit, Municipality of the City of Györ. 
the election office operating alongside the election commission with competence to register the candidate". 4 The name of the recommending voter, their personal identification number, Hungarian address and mother's name shall be entered on the recommendation sheet, and it shall be signed by the voter with their own hand. It is a new rule that the recommendation sheet shall include the name and signature of the person collecting the recommendations. ${ }^{5}$

There are 8 lines for the recommendations on each recommendation sheet. ${ }^{6}$ The form of the recommendation sheet is the following: ${ }^{7}$

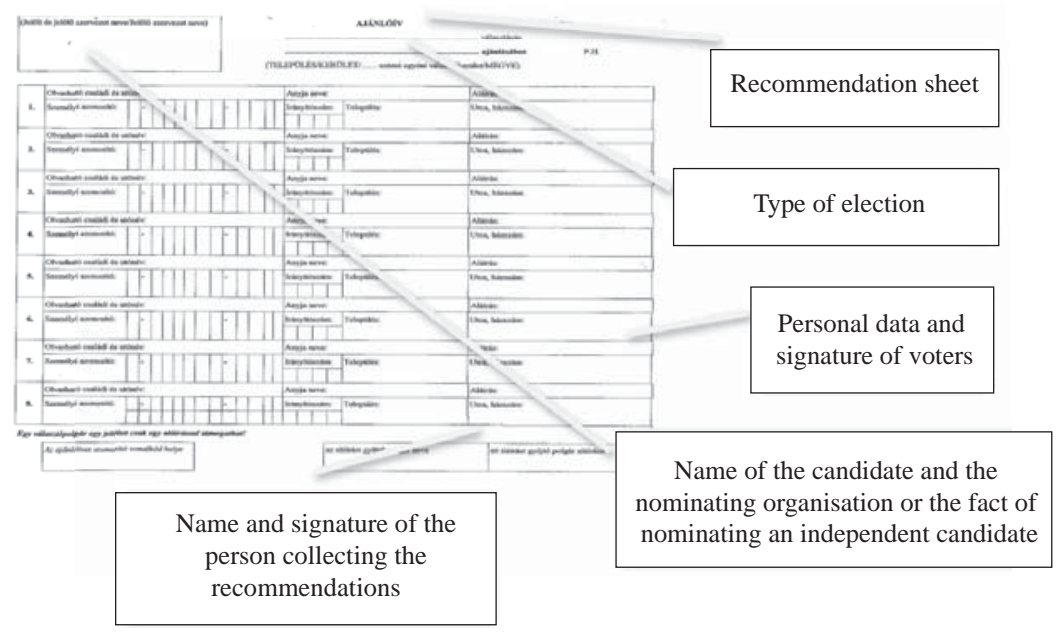

One voter is allowed to recommend more than one candidate. However, he or she is still allowed to recommend one candidate once; "any further recommendations shall be invalid". 8

A reduction in the number of data protection abuses has been expected because of the multiple recommendations and the decrease of the required number of recommendations. In reality, we cannot declare this to be true. We should take into account that parties and candidates are entitled to state support for the election campaigns if they receive enough recommendations and they are registered by the election commissions. ${ }^{9}$ So the fight for recommendations is invariable. It is a fact that bigger parties should not try to obtain as many recommendations as possible, because by doing so they cannot displace small parties from the political scene either.

"Recommendation sheets may be requested (following the call for election) by voters who wish to become candidates and by nominating organizations from the election office

4 Act XXXVI of $2013 \S 120(1)-(2)$.

5 Act XXXVI of $2013 \S 122$ (2), (6).

${ }^{6}$ Decree No. 28/2013. (XI. 15.) KIM of the Ministry of Public Administration and Justice Appendices 20-21.

7 Decree No. 4/2014. (VII. 24.) IM of the Ministry of Justice Appendix 16

8 Act XXXVI of $2013 \S 122$ (3)-(4).

9 When a candidate in Single-member Constituencies is registered by the election commission, (s)he will be entitled to a 1-million Ft state support. The nominating organizations are also entitled to state support, the amount of which depends on the number of their candidates. [Act LXXXVII of $2013 \S 1(1), \S 3(1), \S 4(1), \S 5(1)]$. 
operating alongside the election commission with competence to register the candidate." 10 "The election office shall hand over the recommendation sheets to the applicant without delay but no sooner than on the 48th day before the voting and in the requested quantity." 11 Collecting recommendations can take up to 2 weeks. Candidates shall be notified on the thirty-fourth day before the day of voting at the latest. ${ }^{12}$ All recommendation sheets should be handed over to the election office by this deadline. "In case of a breach of this obligation, the competent election commission shall issue a fine, proceeding ex officio." The fine for every missing recommendation sheet should amount to 50,750 forints in case of elections of Members of Parliament and of the European Parliament, but 10,000 forints concerning municipal elections. "A fine shall not be issued on recommendation sheets handed over one day after the deadline (...) in case the recommendation sheet does not include any recommendations." 13

\section{THE RULES ON CRIMINAL OFFENCES RELATED TO ELECTIONS}

Obtaining nomination by violating the relevant rules by force or the threat of force, by deception or by offering financial benefits is considered a criminal deed. However, not all breaches of rules are qualified as crime.

In general, collecting recommendations is allowed to be done everywhere. But there are some exceptions. ${ }^{14}$ There are some other restrictions, too. These are the following:

1. they should be collected without harassing citizens,

2. advantages shall not be granted or promised to voters for providing a recommendation, and

3. voters shall not ask for or accept an advantage or the promise of an advantage in return for providing a recommendation. ${ }^{15}$

The "simple" breach on the rules leads to the legal consequences named in the act on electoral procedure: recommendations shall be invalid. ${ }^{16}$ But if the rules of nominations are violated by force or threat of force, by deception or by offering financial benefits, it goes with criminal liability. ${ }^{17}$

10 Act XXXVI of $2013 \S 120(2)$.

11 Act XXXVI of $2013 \S 121$ (2).

12 Act XXXVI of $2013 \S 252(1), \S 307 / \mathrm{G}(1), \S 318$ (1).

13 Act XXXVI of $2013 \S 124$ (2)-(3).

14 "Recommendations shall not be collected: a) at the workplace of the person collecting or providing the recommendation during working hours, or while one or the other is fulfilling his or her obligations to perform work arising from employment or other legal relation concerning performance of work; b) from persons in service in the Hungarian Armed Forces or a central administration body at their service post or while they are performing their duty; c) on means of public transport; d) in the official premises of state, municipalities and national minority self-government bodies; e) in higher education and public education institutions; f) on the premises of healthcare providers." [Act XXXVI of $2013 \S 123(2)]$.

15 Act XXXVI of $2013 \S 123$ (1), (3).

16 Act XXXVI of $2013 \S 123$ (4).

17 Criminal Code $\S 350$ (1) a). 
Committing a crime by force means "any act of aggression and undue influence exerted on a person by the application of physical force," even if it does not result in bodily harm. ${ }^{18}$ Moreover, if this act causes some kind of injury, a single cumulative sentence shall be imposed on the person offending the elections and committing battery ${ }^{19}$.

The crime is committed by deception if the criminal misleads somebody in respect of relevant circumstances (for example in respect of the nominating organization) in order to obtain nomination. ${ }^{20}$ According to the former regulation in the past, electors got the proposal coupon by post, which also contained their personal data. It happened that these proposal coupons disappeared from the mailbox. Obtaining these proposal coupons in an illegal way was a criminal act, too. ${ }^{21}$ But nowadays this conduct of gathering proposals cannot happen, because the regulation has been changed.

Threat is not defined by the jurisprudence, but by the Criminal Code. Threat shall mean - unless otherwise stated by law - "a declaration of intention to cause considerable harm so as to make the person who is the target of the threat be afraid of such a declaration". 22

Financial benefits include all kinds of pecuniary advantages. It is sufficient that financial benefits are offered, but this advantage will not necessarily be obtained. This regulation complies with the above-mentioned rule ${ }^{23}$ in the act of electoral procedure. ${ }^{24}$ One of the reasons of the revision of the nomination system was to fight off the misuses in connection with paying money for proposals. It was common to buy the proposal coupons at homeless shelters or via classified ads..$^{25}$

18 Criminal Code $\S 459$ (1) 4.

19 Criminal Code $\S 164$.

20 Busch Béla (ed), Büntetőjog II [Criminal Law II] (HVG-Orac 2012) 553.

${ }^{21}$ Az országgyülési és a helyhatósági képviselőjelölt-ajánlással és a választási kampánnyal kapcsolatos 381/H/2002 adatvédelmi biztosi ajánlás [381/H/2002. recommendation of the Data Protection Commissioner in connection with the nomination of the Members of Parliament and municipal representatives and the electoral campaign] (date: 20/06/2002) http://81.183.229.204:51111/ abi/index.php?menu=beszamolok/2002/5/2\&dok=381_H_2002 (downloaded on 18 September 2014). A Nemzeti Adatvédelmi és Információszabadság Hatóság ajánlása a választási eljárással kapcsolatos adatkezelésekröl [The recommendation of the Hungarian National Authority for Data Protection and Freedom of Information in connection with the data handling during the electoral procedure] (date: 04/02/2014) p. 1. http://www.naih.hu/files/Valasztas-2014-Ajanlas-2014-02-04.pdf (downloaded on 16 September 2014).

22 Criminal Code $\S 459$ (1) 4.

23 Act XXXVI of $2013 \S 123(2)$.

24 Busch 553.

25 Az országgyülési és a helyhatósági képviselőjelölt-ajánlással és a választási kampánnyal kapcsolatos 381/H/2002 adatvédelmi biztosi ajánlás [381/H/2002. recommendation of the Data Protection Commissioner in connection with the nomination of the Members of Parliament and municipal representatives and the electoral campaign] (date: 20/06/2002) http://81.183.229.204:51111/ abi/index.php?menu=beszamolok/2002/5/2\&dok=381_H_2002 (downloaded on 18 September 2014). A Nemzeti Adatvédelmi és Információszabadság Hatóság ajánlása a választási eljárással kapcsolatos adatkezelésekröl [The recommendation of the Hungarian National Authority for Data Protection and Freedom of Information in connection with the data handling during the electoral procedure] (date: 04/02/2014) p. 1. http://www.naih.hu/files/Valasztas-2014-Ajanlas-2014-02-04.pdf (downloaded on 16 September 2014). 


\section{4. “CASE-LAW"}

Court exempts the accused person from the prosecution of the criminal offence related to elections on the grounds that the validity conditions do not exist in the proposal coupons ${ }^{26}$ which were bought. The proposal coupons were blank. I must mention that these proposal coupons were not used in the electoral procedure, and also the candidate ${ }^{27}$ retracted from the nomination.

According to the court the definition of proposal (recommendation) is laid down in the (former) act on electoral procedure. It defines the validity conditions of proposals. They should contain the name of the recommending voter, their personal identification number, address, the name of the candidate and the nominating organisation or the fact of nominating an independent candidate, moreover, the signature of the recommending voter. ${ }^{28}$ If these validity criteria exist, we can speak about a proposal (recommendation). On the basis of the act on electoral procedure the signature should be that of the recommending voter ${ }^{29}$ Other data can be filled in by another person. ${ }^{30}$ If the recommending voter cannot write their signature (e. g. handicapped), their sign-manual ${ }^{31}$ should be authenticated by the head or staff of the election office or court or notary. ${ }^{32}$ It is important to refer to cases when the staff of the election office may encounter correction of personal data while checking the recommendation sheets and this can happen several times. It could indicate misuses, so it is important to notice that these corrections are proper or not. They are correct if the recommending voter locates its signature and the date next to the correction. Both the correction and the recommendation are invalid in the absence of these.

According to the court only valid nominations (recommendations) could be considered as nominations (recommendations). According to the frame disposition an invalid nomination (recommendation) is not a nomination (recommendation).

Even though the personal data are in the possession of the person paying for the recommendation, as it happened in the examined case and "only" the signature had to be falsified. $^{33}$

This kind of approach is dangerous, because it can occur that the voter places his or her signature on the recommendation sheet, however, the personal data are not indicated. These data are filled in by the person collecting the recommendations. It can also happen that the recommendation sheet includes all data, but some of them are false, and for this reason the recommendation sheets cannot be considered as (valid) recommendation. Then,

26 Instead of proposal coupons there are recommendation sheets according to the new act on electoral procedure.

27 The identity of the candidate and that of the person collecting recommendations do not need to coincide. It is true for the case discussed above.

28 Act C of $1997 \S 47$ (2).

${ }^{29}$ Kpkf.II.25009/1992. Supreme Court of Hungary.

30 1/2014. Guidelines of the National Election Committee.

31 The Guidelines of the National Election Committee do not deal with the question of how we should act in case the voter cannot sign their sign-manual on the recommendation sheets either (e.g. paralyzed), but (s)he orally announces the name of the person (s)he would like to support. This has not been regulated yet. However, the Act on electoral procedure lays down that two members of the polling station commission could sign the polling district electoral register, which certifies the handover of the ballot paper. [Act on electoral procedure $\S 179$ (2)].

32 1/2014. Guidelines of the National Election Committee.

33 BH2004. 219. 
if it happens in return for some kind of payment or by force, threat or deception, is it not considered as a criminal offence against elections? These kinds of offenders can claim that they do not obtain recommendations because validity criteria are missing.

Also I must lay down that this behaviour does not fall under forgery ${ }^{34}$ either, as anyone is allowed to fill in the gap on the recommendation sheets, only the signature must originate from a voter. Furthermore, I must refer to the fact that use means only the behaviour suitable for producing legal effect, which does not exist in case of submitting an invalid recommendation.

Another court decided against it: it announced that the question of liability arises in the case of lack of formality (i.e. falsified proposal coupon or recommendation sheet), too. The court went beyond it. It laid down the issue of liability for intellectual forgery ${ }^{35}$ on the grounds that the proposal coupons (recommendation sheets) bought in that way were necessary for becoming a candidate, i.e. false data were fixed in the decision of the election commission with the submission of falsified proposal coupons (recommendation sheets). ${ }^{36}$

The court condemned a criminal for another subsection the criminal offence in question: the criminal was liable for "unauthorized sign" and not for "obtaining nomination in an illegal way" if (s)he obtained unfilled proposal coupons (recommendation sheets) and filled them in. The judgement laid down that (s)he had obtained the blank proposal coupons (recommendation sheets) and (s)he had prepared the falsified documents by using these coupons (sheets) which (s)he had submitted to the election commission. The proposal coupons (recommendation sheets) contained falsified data, since they do not reflect the will of voters and the signatures were falsified, too. This behaviour is called forgery, but the criminal is not liable for this crime as it would not comply with the principle "ne bis in idem". (S)He is liable only for the criminal offence related to elections.

According to the court's point of view the question of liability does not come up as a legal result of intellectual forgery, because the candidate was registered on the grounds of these falsified proposal coupons (recommendation sheets). However, the decision of the election commission was wrong because of these falsified documents. It could harm the principle of " $n$ e bis in idem". ${ }^{37}$

\section{RELEVANCE OF THE STUDY}

The above-mentioned discussion has a practical relevance, too. There is a suspicion that some nominating organizations exchanged the personal data given on their recommendation sheets in the election of Members of Parliament in 2014. The "fight" went for the state support. In connection with that, many requests have arrived to election offices concerning which nominating organizations' recommendation sheets included their personal data.

34 Section 345. Any person who uses a falsified or forged private document or a private document of untrue contents for providing evidence for the existence, the changing or termination of a right or obligation, is guilty of a misdemeanour, punishable by imprisonment not exceeding one year. [Criminal Code $\S 345]$.

35 Criminal Offences with Authentic Instruments Section 346 (1) Any person who - as regards any authentic instrument which does not belong to him or which is not exclusively his own: (...) c) unlawfully commandeers or conceals such authentic instrument from its rightful holder; is guilty of a misdemeanour punishable by imprisonment not exceeding two years. [Criminal Code $\$ 346$ (1) c)].

36 5.B.645/2007/21. Regional Court of Veszprém.

37 Bf.40/2008/4. Regional Court of Appeal, Györ. 
I must emphasize that the authenticity of the signatures on recommendation sheets cannot be examined by election offices. They have no sphere of authority and measure for it. "The identification of the recommending voter and the determination of their right to vote shall be carried out by comparing the data indicated on the recommendation sheet with the information in the central electoral register and the register of polling districts and constituencies." 38 There is no further measure. Investigation authorities have only the sphere of authority to investigate a crime. The criminal procedure has begun in several cases, so some of the recommendation sheets have been confiscated by the police. ${ }^{39}$

The accused made a contract with a company settled in Budapest and ordered them to search for candidates in the election of Members of Parliament and they were to collect the necessary number of nominations for three smaller parties. This does not violate the law. But there was a problem: they could not collect the necessary number of nominations in time, thus they had to pay for the voters' personal data collected by other parties and falsify the voters' signatures on the recommendation sheets. The falsified recommendation sheets were submitted to the election offices on the last day. According to the indictment the people concerned did not want to enter the election as a candidate. ${ }^{40}$ So it is supposed that their signatures had to be falsified on the recommendation sheets. ${ }^{41}$ The election commissions rejected the registration as a candidate because of the falsified signatures. It is an interesting question how the election office could check the authenticity of the signatures because they did not have such sphere of authority.

From the perspective of classification it is significant whether the candidates were registered or their registrations were rejected. In my opinion, if the person is registered as a candidate, the election commission decides about the registration on the grounds of falsified data. These falsified data are the basis of the decision. The decision is a false authentic document. So it is an act of forgery, too, and not only a criminal offence related to elections.

It is an important question how to act if the unlawfulness of the registration turns out only after the election or the legally binding result. How can this illegal situation be remedied? Anyway, the accused person has the right for the presumption of innocence till the finalization of the judgement of criminal liability, too.

38 Act XXXVI of $2013 \S 125$ (3).

39 A Nemzeti Adatvédelmi és Információszabadság Hatóság közleménye a jelöltállítási rendszerrel kapcsolatban felmerült visszaélések vizsgálatáról [The announcement of the Hungarian National Authority for Data Protection and Freedom of Information about the examination in connection with misuses of nomination system] (date: 18/03/2014) http://www.naih.hu/files/NAIHkozlemeny-jeloltall-2014_03_18.pdf (downloaded on 17 September 2014). NAIH-703-3/2014/V 703/2014. standpoint http://www.naih.hu/files/703 2014_allasfoglalas_ajanloivek_taj_jogrol.pdf (downloaded on 21 September 2014) NAIH-712-2/2014/V - 712/2014. standpoint http://www.naih. hu/files/712_2014_allasfoglalas.pdf (downloaded on 22 September 2014).

40 Nyolcan állnak bíróság elé választási hamisítás miatt [Eight people stand in front of the court because of electoral forgery] http://www.origo.hu/itthon/20141107-nyolcan-allnak-birosag-elevalasztasi-hamisitas-miatt.html (downloaded on 19 December 2014).

41 Decree No. 28/2013. (XI. 15.) KIM Appendices 18-19, 22, Decree No. 4/2014. (VII. 24.) IM Appendices 12-15 and 17-18. 


\section{OTHER CRIMES IN CONNECTION WITH ELECTIONS}

\subsection{The misuse of personal data}

The "simple" violation of the statutory provisions governing the protection and processing of personal data does not result in criminal liability, only in case it imposes significant injury on the interests of another person or persons (e.g. it concerns a lot of persons), or if it is committed for unlawful financial gain. ${ }^{42}$

I referred above to what kinds of misuses were committed in the election of Members of Parliament in 2014: the smaller parties exchanged the data of the recommending voters among each other. It provided the condition for the registration as a candidate. This behaviour constitutes the crime of the misuse of personal data, too, regardless of the fact whether it is committed for unlawful financial gain, since in each case it imposes significant injury on the interests of another person or persons (e.g. it concerns a lot of persons). Both data provider and data recipient are liable for it. Both of them constitute the subspecies of unauthorized personal data processing since data processing includes data collection and data transmission. ${ }^{43}$

To my mind the misuse of personal data stands with the criminal offence related to elections in seemingly formal cumulative sentence, since in respect of the recommendation sheets the phrase "unauthorized sign" means unauthorized personal data processing, too. The person who transmits the data is liable for the misuse of personal data.

\subsection{Budget fraud}

It is worth to think about why the idea of exchange of personal data came up in the election of Members of Parliament. In the election of Members of Parliament both parties and candidates get state support for their election campaign. Individual candidates could get an amount of one million HUF as regards state supports. Nominating organizations get a certain percentage of the basic state support defined in the act (the multiplication of 5 million HUF and the number of mandates acquired in the election of Members of Parliament). The percentage was determined by the number of candidates set in constituencies. These rates were the following:

a) $15 \%$ of the basic state support if candidates are set in at least 27 ,

b) $30 \%$ in case of at least 54 ,

42 Misuse of Personal Data Section 219 (1) Any person who, in violation of the statutory provisions governing the protection and processing of personal data, a) is engaged in the unauthorized and inappropriate processing of personal data; or b) fails to take measures to ensure the security of data; and it imposes significant injury on interests, or it is committed for unlawful financial gain, is guilty of a misdemeanour punishable by imprisonment not exceeding one year. (2) The penalty in accordance with Subsection (1) above shall also be imposed upon any person who, in violation of the statutory provisions governing the protection and processing of personal data, fails to notify the data subject as required, and thereby imposes significant injury on the interests of another person or persons. (3) Any misuse of personal data shall be punished by imprisonment not exceeding two years if committed in connection with special data. (4) The penalty shall be imprisonment not exceeding three years for a felony if the misuse of personal data is committed by a public official or in the course of discharging a public duty. [Criminal Code § 219].

43 Act CXII of $2011 \S 3$ clause 10. 
c) $45 \%$ in case of at least 80 ,

d) $60 \%$ in case of all

Single-member Constituencies. ${ }^{44}$

Therefore I must mention the budget fraud in connection with the proof of eligibility to state aid: as any person who induces a person to hold or continue to hold a false belief, or suppresses known facts in connection with any funds paid or payable from the budget, or makes a false statement to this extent and thereby causes financial loss to one or more budgets. ${ }^{45}$

So I must confirm that the above-mentioned perpetration constitutes two crimes: the criminal offence related to elections and the budget fraud.

\section{SUMMARY}

The year 2014 was a significant period for the legislation and law enforcement. This study examines some types of criminal offences related to elections. With the passing of current rules several misuses have vanished or the number of them has decreased. However, the new legal institutions pose new challenges. The coming years are a calmer period from the perspective of elections, thus, the legislator has enough time to make conclusions on the grounds of experiences gained in 2014 and to pass the appropriate rules.

We must not forget the fact that elections are the basics of democratic political power. ${ }^{46}$ Therefore it is very important that the misuses concerning elections should be fought off as effectively as possible. And if it happens, criminal, civil or other liability must be ascertained. ${ }^{47}$

\section{LITERATURE}

Busch, B. (ed), Büntetöjog II [Criminal Law II] (HVG-Orac 2012).

Nagy, F. (ed.), Bünügyi mozaik. Tanulmányok Vida Mihály 70. születésnapja tiszteletére [Criminal Mosaic. Studies in Honour of Vida Mihály on His 70th Birthday] (Pólay Elemér Alapítvány 2006) 427-438.

Ruszoly, J., 'Választási büncselekmények és választásérvénytelenítési okok' [Electoral Criminal Offences and Reasons of Invalidation] in Tóth, K., 'Megelőzhető választási csalások' [Preventable Electoral Fraud] in Cserny Ákos and Téglási András (eds), Tanulmányok a választási eljárás aktuális kérdéseiröl [Studies about the Current Questions of Electoral Procedure] (Nemzeti Közszolgálati Egyetem 2013) 109-118.

${ }^{44}$ Act LXXXVII of $2013 \S 1$ (1), § 3 (1), § 5 (1).

45 Criminal Code $\S 396$.

46 Ruszoly József, 'Választási büncselekmények és választásérvénytelenítési okok’ [Electoral Criminal Offences and Reasons of Invalidation] in Nagy Ferenc (ed.), Bünügyi mozaik. Tanulmányok Vida Mihály 70. születésnapja tiszteletére [Criminal Mosaic. Studies in Honour of Vida Mihály on His 70th Birthday] (Pólay Elemér Alapítvány 2006) 427.

47 Tóth Károly, 'Megelőzhető választási csalások' [Preventable Electoral Fraud] in Cserny Ákos and Téglási András (eds), Tanulmányok a választási eljárás aktuális kérdéseiröl [Studies about the Current Questions of Electoral Procedure] (Nemzeti Közszolgálati Egyetem 2013) 109-110. 